\title{
Thermodynamic Analysis and Preparation of Composites in Zr-Si-C-N-O System
}

\author{
Yu Renhong, Zhou Ningsheng, Zhang Feifei \\ Henan University of Science and Technology, Luoyang 471003, China
}

\begin{abstract}
In order to obtain the diagrams of stability relations (namely, predominance area phase diagram, PAPD) for carbothermal reduction and nitridation (CRN) of zircon, the thermodynamic calculation and the analysis on the Zr-Si-C-N-O system were carried on by the method of $\Delta_{\mathrm{f}} G_{i}^{\Theta}=A+B T$, and PAPD of the $\mathrm{Zr}-\mathrm{Si}-\mathrm{C}-\mathrm{N}-\mathrm{O}$ system was constructed. The CRN of zircon may lead to the formation of different oxide-nitride composites such as $\mathrm{ZrO}_{2}-\mathrm{Si}_{2} \mathrm{~N}_{2} \mathrm{O}, \mathrm{ZrN}-\mathrm{Si}_{2} \mathrm{~N}_{2} \mathrm{O}$, and $\mathrm{ZrN}-\mathrm{Si}_{3} \mathrm{~N}_{4}$ by controlling reaction conditions of carbon proportion, temperature, and partial pressures of $\mathrm{CO}$ and $\mathrm{N}_{2}$. Zircon powder (45 $\left.\mu \mathrm{m}\right)$, activated carbon and $\mathrm{N}_{2}(99.999 \%)$ were used as the starting materials, the effect of carbon proportion on the mass loss and the product phase composition after CRN of zircon was investigated. Carbon proportion affects the yielded reaction products obviously; and the higher the carbon proportion, the lower the starting temperature for the $\mathrm{CRN}$ to occur.
\end{abstract}

Key words: zircon; carbothermal reduction and nitridation (CRN); thermodynamic analysis; predominance area phase diagram (PAPD); carbon proportion

Carbothermal reduction and nitridation $(\mathrm{CRN})$ is one of common ways to prepare relatively less costly nonoxides or oxide-nonoxide composite powders for high temperature materials. The costs of these composite powders can be further reduced by using natural raw materials. On the other hand, by using CRN method, the obtained composite powders are usually perfectly homogenized. It is possible to obtain a wide variety of nitrides or oxide-nonoxide composite powders with great scientific and technological interest such as $\mathrm{ZrN}_{-} \mathrm{Si}_{3} \mathrm{~N}_{4}^{[1-3]}, \mathrm{ZrO}_{2}-\mathrm{Si}_{2} \mathrm{~N}_{2} \mathrm{O}^{[4,5]}$ and $\mathrm{Zr}(\mathrm{C}, \mathrm{N}, \mathrm{O})^{[6]}$ quaternary phases by $\mathrm{CRN}$ of zircon.

However, the reaction complexity may bring many products during the $\mathrm{CRN}$ of zircon, for example, $\mathrm{ZrN}, \mathrm{ZrC}$, $\mathrm{ZrO}_{2}-\mathrm{Si}_{2} \mathrm{~N}_{2} \mathrm{O}, \mathrm{ZrO}_{2}-\mathrm{SiC}, \mathrm{ZrN}-\mathrm{Si}_{2} \mathrm{~N}_{2} \mathrm{O}$ and $\mathrm{ZrN}-\mathrm{Si}_{3} \mathrm{~N}_{4}$, etc.. The products obtained depend not only on the raw materials used but also on the reaction condition, such as reaction temperature, atmosphere and carbon proportion. Therefore, the thermodynamic calculation and the analysis of $\mathrm{Zr}-\mathrm{Si}-\mathrm{C}-\mathrm{N}-\mathrm{O}$ system can supply the theory basis for the choice of relevant technological parameters.
The correlation of $\mathrm{Zr}-\mathrm{Si}-\mathrm{C}-\mathrm{N}-\mathrm{O}$ system at different temperatures and under different partial pressures of $\mathrm{CO}$ was analyzed by thermodynamic calculation, the predominance area phase diagram (PAPD) of Zr-Si-C-N-O system was constructed, and the effect of carbon proportion on reaction products was researched.

\section{Thermodynamic Calculation and Analysis}

1.1 Phase relationship at different temperatures and under different $\mathrm{CO}$ partial pressures

The CRN of zircon belongs to $\mathrm{Zr}-\mathrm{Si}$-C-N-O system. In this system, the important condensation phases are $\mathrm{SiO}_{2}, \mathrm{ZrO}_{2}$, $\mathrm{SiC}, \mathrm{ZrC}, \mathrm{Si}_{3} \mathrm{~N}_{4}, \mathrm{ZrN}, \mathrm{Si}_{2} \mathrm{~N}_{2} \mathrm{O}$ and carbon. Table 1 lists the standard Gibbs free energy of the formation of some compounds and elements ${ }^{[7]}$.

According to the thermodynamics data in Table1, the standard Gibbs free energy changes $\left(\Delta_{\mathrm{r}} G^{\Theta}\right)$ for reactions in the $\mathrm{Zr}-\mathrm{Si}-\mathrm{C}-\mathrm{N}-\mathrm{O}$ system were calculated and the results are shown in Table 2.

Received date: January 15, 2013

Foundation item: Natural Science Foundation of Henan Educational Committee (2011B430011)

Corresponding author: Yu Renhong, Ph. D., Associate Professor, High Temperature Materials Institute, Henan University of Science and Technology, Luoyang 471003, P. R. China, Tel: 0086-379-64231460, E-mail: yurenhong_wby@ sina.com 
Table 1 Standard Gibbs free energy of formation of different compounds

\begin{tabular}{ccc}
\hline Reaction equations & $\Delta_{\mathrm{f}} G^{\Theta}=A+B T / \mathrm{J} \cdot \mathrm{mol}^{-1}$ & Temperature $/{ }^{\circ} \mathrm{C}$ \\
\hline $\mathrm{C}(\mathrm{s})+0.5 \mathrm{O}_{2}(\mathrm{~g})=\mathrm{CO}(\mathrm{g})$ & $-114400-85.77 T$ & $500 \sim 2000$ \\
$\mathrm{Si}(\mathrm{s})=\mathrm{Si}(\mathrm{l})$ & $50540-30.0 T$ & 1412 \\
$\mathrm{Si}(\mathrm{l})+\mathrm{C}(\mathrm{s})=\mathrm{SiC}(\mathrm{s})$ & $-114400+37.2 T$ & $1412 \sim 1727$ \\
$3 \mathrm{Si}(\mathrm{l})+2 \mathrm{~N}_{2}(\mathrm{~g})=\mathrm{Si}_{3} \mathrm{~N}_{4}(\mathrm{~s})$ & $-874456+405.01 T$ & $1412 \sim 1700$ \\
$\mathrm{Si}(\mathrm{l})+\mathrm{O}_{2}(\mathrm{~g})=\mathrm{SiO}_{2}(\mathrm{~s})$ & $-946350+197.64 T$ & $1412 \sim 1723$ \\
$2 \mathrm{Si}(\mathrm{l})+\mathrm{N}_{2}(\mathrm{~g})+0.5 \mathrm{O}_{2}(\mathrm{~g})=$ & $-951651+290.57 T$ & $1412 \sim 2000$ \\
$\mathrm{Si}_{2} \mathrm{~N}_{2} \mathrm{O}(\mathrm{s})$ & & \\
$\mathrm{Zr}(\mathrm{s})+\mathrm{O}_{2}(\mathrm{~g})=\mathrm{ZrO}_{2}(\mathrm{~s})$ & $-1092000+183.7 T$ & $25 \sim 1850$ \\
$\mathrm{Zr}(\mathrm{s})+0.5 \mathrm{~N}_{2}(\mathrm{~g})=\mathrm{ZrN}(\mathrm{s})$ & $-363600+92.0 T$ & $25 \sim 1850$ \\
$\mathrm{Zr}(\mathrm{s})+\mathrm{C}(\mathrm{s})=\mathrm{ZrC}(\mathrm{s})$ & $-196650+9.2 T$ & $25 \sim 1850$ \\
\hline
\end{tabular}

Table 2 Standard Gibbs free energy changes for the reactions in the $\mathrm{Zr}$-Si-C-N-O system

\begin{tabular}{|c|c|c|}
\hline Reaction equations & $\Delta_{\mathrm{f}} G^{\Theta}=A+B T / \mathrm{J} \cdot \mathrm{mol}^{-1}$ & Equation No. \\
\hline $\mathrm{ZrO}_{2}(\mathrm{~s})+3 \mathrm{C}(\mathrm{s})=\mathrm{ZrC}(\mathrm{s})+2 \mathrm{CO}(\mathrm{g})$ & $666550-346.04 T$ & 1 \\
\hline $\begin{array}{r}\mathrm{ZrO}_{2}(\mathrm{~s})+2 \mathrm{C}(\mathrm{s})+0.5 \mathrm{~N}_{2}(\mathrm{~g})= \\
\mathrm{ZrN}(\mathrm{s})+2 \mathrm{CO}(\mathrm{g})\end{array}$ & $499600-263.24 T$ & 2 \\
\hline $\mathrm{ZrC}(\mathrm{s})+0.5 \mathrm{~N}_{2}(\mathrm{~g})=\mathrm{ZrN}(\mathrm{s})+\mathrm{C}(\mathrm{s})$ & $-166950+82.8 T$ & 3 \\
\hline $\begin{array}{l}2 \mathrm{SiO}_{2}(\mathrm{~s})+3 \mathrm{C}(\mathrm{s})+\mathrm{N}_{2}(\mathrm{~g})= \\
\mathrm{Si}_{2} \mathrm{~N}_{2} \mathrm{O}(\mathrm{s})+3 \mathrm{CO}(\mathrm{g})\end{array}$ & 597849-362.02T & 4 \\
\hline $\mathrm{SiO}_{2}(\mathrm{~s})+3 \mathrm{C}(\mathrm{s})=\mathrm{SiC}(\mathrm{s})+2 \mathrm{CO}(\mathrm{g})$ & $603150-331.98 T$ & 5 \\
\hline $\begin{aligned} \mathrm{Si}_{2} \mathrm{~N}_{2} \mathrm{O}(\mathrm{s})+3 \mathrm{C}(\mathrm{s})= & 2 \mathrm{SiC}(\mathrm{s})+ \\
& \mathrm{CO}(\mathrm{g})+\mathrm{N}_{2}(\mathrm{~g})\end{aligned}$ & 608451-301.94T & 6 \\
\hline $\begin{array}{r}2 \mathrm{Si}_{2} \mathrm{~N}_{2} \mathrm{O}(\mathrm{s})+\mathrm{C}(\mathrm{s})+2 / 3 \mathrm{~N}_{2}(\mathrm{~g})= \\
4 / 3 \mathrm{Si}_{3} \mathrm{~N}_{4}(\mathrm{~s})+2 \mathrm{CO}(\mathrm{g})\end{array}$ & $508561-212.67 T$ & 7 \\
\hline $3 \mathrm{SiC}(\mathrm{s})+2 \mathrm{~N}_{2}(\mathrm{~g})=\mathrm{Si}_{3} \mathrm{~N}_{4}(\mathrm{~s})+3 \mathrm{C}(\mathrm{s})$ & $-531256+293.41 T$ & 8 \\
\hline $\mathrm{ZrSiO}_{4}(\mathrm{~s})=\mathrm{ZrO}_{2}(\mathrm{~s})+\mathrm{SiO}_{2}(\mathrm{~s})$ & $25496-13.08 T$ & 9 \\
\hline $\begin{array}{l}2 \mathrm{ZrSiO}_{4}(\mathrm{~s})+3 \mathrm{C}(\mathrm{s})+\mathrm{N}_{2}(\mathrm{~g})= \\
2 \mathrm{ZrO}_{2}(\mathrm{~s})+\mathrm{Si}_{2} \mathrm{~N}_{2} \mathrm{O}(\mathrm{s})+3 \mathrm{CO}(\mathrm{g})\end{array}$ & $648840-388.25 T$ & 10 \\
\hline
\end{tabular}

According to $\Delta_{\mathrm{r}} G^{\theta}$ data of the reactions in Table 2, the relationship between $R T \ln \left(P_{\mathrm{CO}} / P^{\theta}\right)$ and temperature of the reactions (namely PAPD) was plotted. When $P_{\mathrm{N}_{2}}=0.1 \mathrm{MPa}=P^{\theta}$, PAPD of $\mathrm{Zr}-\mathrm{Si}-\mathrm{C}-\mathrm{N}-\mathrm{O}$ system with excessive carbon is shown in Fig.1.

Fig. 1 shows that when carbon is excessive, there may be many different products as the temperature and the partial pressure of $\mathrm{CO}$ change during the $\mathrm{CRN}$ of zircon. For example, when the temperature is $1500{ }^{\circ} \mathrm{C}(1773 \mathrm{~K})$, with $\mathrm{CO}$ partial pressure decreasing, the products change as follows: $\mathrm{ZrSiO}_{4} \rightarrow$

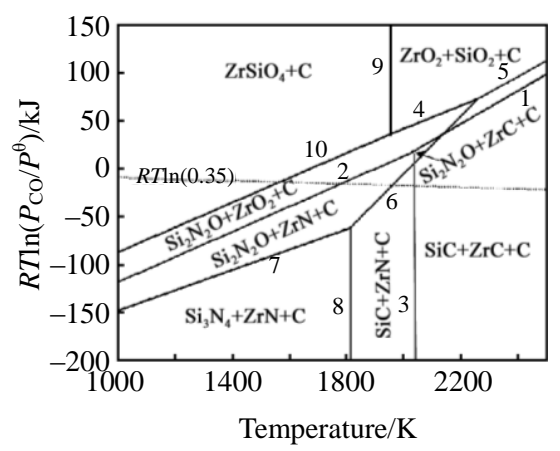

Fig.1 PAPD for the Zr-Si-C-N-O system when $P_{\mathrm{N}_{2}}=0.1 \mathrm{MPa}$
$\mathrm{Si}_{2} \mathrm{~N}_{2} \mathrm{O}+\mathrm{ZrO}_{2} \rightarrow \mathrm{Si}_{2} \mathrm{~N}_{2} \mathrm{O}+\mathrm{ZrN} \rightarrow \mathrm{Si}_{3} \mathrm{~N}_{4}+\mathrm{ZrN}$. It can be seen from Fig. 1 there is no coexistence area for $\mathrm{Si}_{3} \mathrm{~N}_{4}$ and $\mathrm{ZrO}_{2}$, which means it is infeasible to prepare $\mathrm{ZrO}_{2}-\mathrm{Si}_{3} \mathrm{~N}_{4}$ composite powder by CRN.

For an industrial production, the $\mathrm{CRN}$ is often carried out in carbon-embedded condition in air, and $\mathrm{CO}$ partial pressure is $0.035 \mathrm{MPa}$ and $\mathrm{N}_{2}$ partial pressure is $0.065 \mathrm{MPa}$. The thermodynamics calculation shows that when the reaction temperature is lower than $1306{ }^{\circ} \mathrm{C}, \mathrm{ZrSiO}_{4}$ is stabilized phase; when 1306 1518 ${ }^{\circ} \mathrm{C}, \mathrm{Si}_{2} \mathrm{~N}_{2} \mathrm{O}+\mathrm{ZrO}_{2}$; when $1518 \sim 1663{ }^{\circ} \mathrm{C}$, $\mathrm{Si}_{2} \mathrm{~N}_{2} \mathrm{O}+\mathrm{ZrN}$; when $1663 \sim 1743{ }^{\circ} \mathrm{C}, \mathrm{SiC}+\mathrm{ZrN}$; when over $1743{ }^{\circ} \mathrm{C}, \mathrm{SiC}+\mathrm{ZrC}$. It can be seen that $\mathrm{Si}_{3} \mathrm{~N}_{4}$ is unstabilized phase when the CRN of zircon is carried out in carbon-embedded condition in air.

\subsection{Phase relationship at same temperature and under different partial pressures}

When an excessive carbon coexists, the stability relationship of phases in the Zr-Si-C-N-O system has relation not only to the temperature, but also to the partial pressures of $\mathrm{CO}$ and $\mathrm{N}_{2}$. Therefore, at a given temperature, the stability relationship of phases in the $\mathrm{Zr}-\mathrm{Si}-\mathrm{C}-\mathrm{N}-\mathrm{O}$ system should be a function of $\mathrm{CO}$ and $\mathrm{N}_{2}$ partial pressure.

According to the data in Table 2, the relationship of $\ln \left(P_{\mathrm{CO}} / P^{\theta}\right)-\ln \left(P_{\mathrm{N}_{2}} / P^{\theta}\right)$ for reactions in $\mathrm{Zr}$-Si-C-N-O system can be calculated. PAPD of the $\mathrm{Zr}-\mathrm{Si}-\mathrm{C}-\mathrm{N}-\mathrm{O}$ system under various $\mathrm{CO}$ and $\mathrm{N}_{2}$ partial pressure at given temperatures is plotted, as shown in Fig.2.

According to Fig.2, when the temperature is given, the products of the $\mathrm{CRN}$ of zircon vary with the partial pressures of $\mathrm{N}_{2}$ and CO. For example, at $1723 \mathrm{~K}\left(1450{ }^{\circ} \mathrm{C}\right)$ and when the partial pressure of $\mathrm{N}_{2}$ is equal to $101325 \mathrm{~Pa}$, with $\mathrm{CO}$ partial pressure decreasing the products of the $\mathrm{CRN}$ of zircon change as follows: $\mathrm{ZrSiO}_{4} \rightarrow \mathrm{Si}_{2} \mathrm{~N}_{2} \mathrm{O}+\mathrm{ZrO}_{2} \rightarrow \mathrm{Si}_{2} \mathrm{~N}_{2} \mathrm{O}+\mathrm{ZrN} \rightarrow$ $\mathrm{Si}_{3} \mathrm{~N}_{4}+\mathrm{ZrN}$; at $1823 \mathrm{~K}\left(1550{ }^{\circ} \mathrm{C}\right)$, the products change as follows: with $\mathrm{CO}$ partial pressure decreasing, $\mathrm{ZrSiO}_{4} \rightarrow$ $\mathrm{Si}_{2} \mathrm{~N}_{2} \mathrm{O}+\mathrm{ZrO}_{2} \rightarrow \mathrm{Si}_{2} \mathrm{~N}_{2} \mathrm{O}+\mathrm{ZrN} \rightarrow \mathrm{SiC}+\mathrm{ZrN}$. At $1773 \mathrm{~K}$

( $1500{ }^{\circ} \mathrm{C}$ ) , when the partial pressure of $\mathrm{N}_{2}$ is equal to 101 $325 \mathrm{~Pa}$, to obtain $\mathrm{Si}_{3} \mathrm{~N}_{4}+\mathrm{ZrN}$ composite powder, $\mathrm{CO}$ partial pressure must be lower than $1172 \mathrm{~Pa}$, otherwise, the products will be $\mathrm{Si}_{2} \mathrm{~N}_{2} \mathrm{O}+\mathrm{ZrN}$ or $\mathrm{Si}_{2} \mathrm{~N}_{2} \mathrm{O}+\mathrm{ZrO}_{2}$.

\section{Experiment}

\subsection{Specimen preparation}

Commercially available zircon powder $(45 \mu \mathrm{m})$ was used as the starting material. The chemical analysis of the powder, given by the manufacturer, is as follows: $66.59 \% \mathrm{ZrO}_{2}$, $32.52 \% \quad \mathrm{SiO}_{2}, 0.19 \% \quad \mathrm{TiO}_{2}$ and $0.08 \% \quad \mathrm{Fe}_{2} \mathrm{O}_{3}$. Commercial activated carbon( analytical reagent, $\mathrm{AR}$ ) was used as carbon source and $\mathrm{N}_{2}$ with $99.999 \%$ of purity $\left(\mathrm{O}_{2} \leqslant 3.0 \times 10^{-6}, \mathrm{H}_{2} \mathrm{O} \leqslant\right.$ $5.0 \times 10^{-6}$ ) as nitrogen source.

The thermodynamics analysis results show that different carbon proportions result in the formation of different reaction products during the $\mathrm{CRN}$ of zircon. According to Fig.1, the 

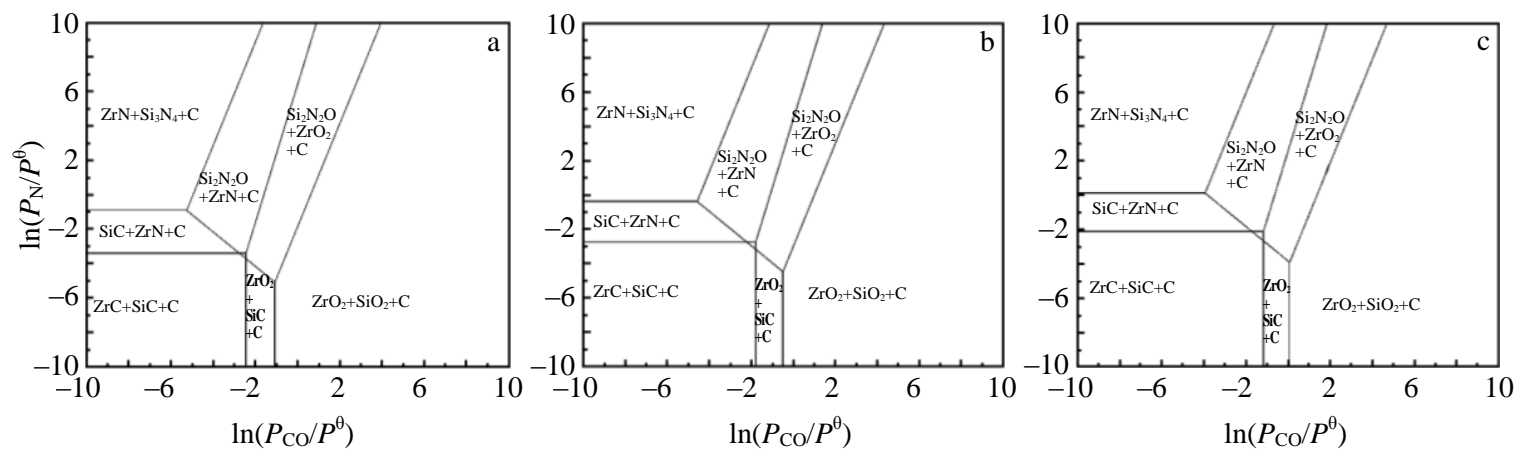

Fig.2 PAPD for the Zr-Si-C-N-O system at given temperatures: (a) $1723 \mathrm{~K}$, (b) $1773 \mathrm{~K}$, and (c) $1823 \mathrm{~K}$

chemical reactions and their theoretical mass losses for the calculation of carbon proportions are shown in Table 3.

Considering a possible carbon loss in the preparation of specimens the actual carbon proportion should be slightly higher than the theoretical value, the actual carbon proportion was therefore set at $10 \%, 20 \%, 22 \%$ and $30 \%$, respectively. The specimens were coded by a letter A, for activated carbon, followed by carbon proportion data. In this way, we obtained A10 (carbon proportion 10\%), A20 (carbon proportion 20\%), A22 (carbon proportion 22\%) and A30 (carbon proportion $30 \%$ ) specimens.

Using water as disperse medium, the starting materials were wet-mixed for $24 \mathrm{~h}$ in a ball mill according to the calculated amounts, dried at $110{ }^{\circ} \mathrm{C}$ for $24 \mathrm{~h}$ and then pressed under 50 $\mathrm{MPa}$ into the cylinder specimens with $8 \sim 10 \mathrm{~mm}$ in height and $36 \mathrm{~mm}$ in diameter. After dried at $110{ }^{\circ} \mathrm{C}$ for $24 \mathrm{~h}$, the specimens were put in a graphite crucible; the crucible was placed in an atmosphere-controlled muffle furnace with $\mathrm{MoSi}_{2}$ heating elements, heated to $1450,1500{ }^{\circ} \mathrm{C}$ and soaked for $4 \mathrm{~h}$ and then cooled to ambient temperature along the furnace. The reactions were performed in nitrogen atmosphere with a gas flow rate of $500 \mathrm{~L} \cdot \mathrm{h}^{-1}$. In all experiments a $\mathrm{N}_{2}$ pressure of 0.02 MPa above the atmospheric pressure was used.

\subsection{Properties testing}

The phase composition after reaction was characterized by XRD with Philips $X^{\prime}$ Pert Pro MPD equipment using $\mathrm{Cu}-\mathrm{K} \alpha$ radiation and $\mathrm{Ni}$ filter at $40 \mathrm{kV}$ and $40 \mathrm{~mA}$. The scanning was made at room temperature between $6^{\circ}$ and $76^{\circ}$ in $2 \theta$ with step

Table 3 Carbon proportion and theoretical mass loss of different reactions $(\mathrm{wt} \%)$

\begin{tabular}{|c|c|c|}
\hline Reaction equations & $\begin{array}{c}\text { Carbon } \\
\text { proportion }\end{array}$ & $\begin{array}{l}\text { Theoretical } \\
\text { mass loss }\end{array}$ \\
\hline $\begin{array}{l}2 \mathrm{ZrSiO}_{4}+3 \mathrm{C}+\mathrm{N}_{2}= \\
\quad \mathrm{Si}_{2} \mathrm{~N}_{2} \mathrm{O}+2 \mathrm{ZrO}_{2}+3 \mathrm{CO}\end{array}$ & 8.95 & 13.9 \\
\hline $\begin{array}{l}2 \mathrm{ZrSiO}_{4}+7 \mathrm{C}+2 \mathrm{~N}_{2}= \\
\mathrm{Si}_{2} \mathrm{~N}_{2} \mathrm{O}+2 \mathrm{ZrN}+7 \mathrm{CO}\end{array}$ & 18.7 & 31.1 \\
\hline $\begin{array}{l}6 \mathrm{ZrSiO}_{4}+24 \mathrm{C}+7 \mathrm{~N}_{2}= \\
2 \mathrm{Si}_{3} \mathrm{~N}_{4}+6 \mathrm{ZrN}+24 \mathrm{CO}\end{array}$ & 20.8 & 34.3 \\
\hline $\mathrm{ZrSiO}_{4}+6 \mathrm{C}=\mathrm{SiC}+\mathrm{ZrC}+4 \mathrm{CO}$ & 28.2 & 43.9 \\
\hline
\end{tabular}

size of $0.02^{\circ}$ and a step counting time of $2 \mathrm{~s}$. The crystalline phases were expressed in mass fraction (wt $\%$ ), and percentages of different phases were calculated by a RIR method.

$$
W_{x}=\frac{I_{x}}{K_{x}\left(I_{1} / K_{1}+I_{2} / K_{2}+\ldots \ldots+I_{n} / K_{n}\right)} \times 100 \%
$$

where, $W_{x}$ is the relative content of $x$ phase in the sample, $L_{x}$ is the absolute intensities of diffraction peaks of $x$ phase and $K_{x}$ is the RIR value of $x$ phase

The CRN of zircon is followed by the mass loss, the mass change is determined by weighting the specimens before and after heat treatment to calculate the actual mass loss ratio for characterizing the reaction degree of the specimen.

$$
W_{\mathrm{L}}=\frac{m_{1}-m_{2}}{m_{1}} \times 100 \%
$$

where, $W_{\mathrm{L}}$ is the actual mass loss ratio of specimen, $m_{1}$ is the specimen mass before the reaction, and $m_{2}$ is the specimen mass after the reaction.

\section{Results and Discussion}

\subsection{Effect of carbon proportion on mass loss ratio and phase containing silica of the specimens}

The comparison of the actual mass loss ratio and the theoretical mass loss ratio of all the specimens after reacted at $1500{ }^{\circ} \mathrm{C}$ is shown in Fig.3. The effects of carbon proportion on the ratio of $\mathrm{Si}_{2} \mathrm{~N}_{2} \mathrm{O}$ and the decomposed zircon and the contents of $\mathrm{ZrSiO}_{4}$ are shown in Fig.4a and Fig.4b, respectively.

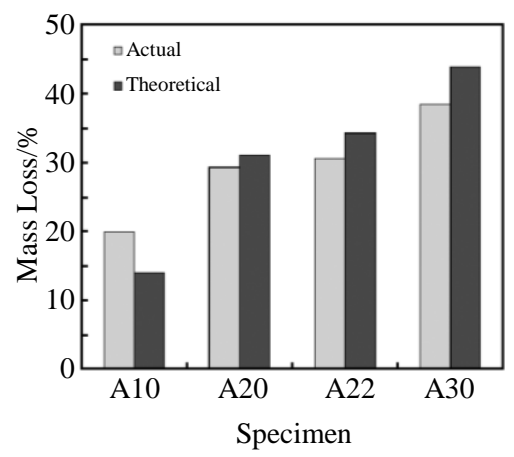

Fig.3 Effect of carbon proportion on mass loss of CRN of zircon after reacted at $1500{ }^{\circ} \mathrm{C}$ for $4 \mathrm{~h}$ 

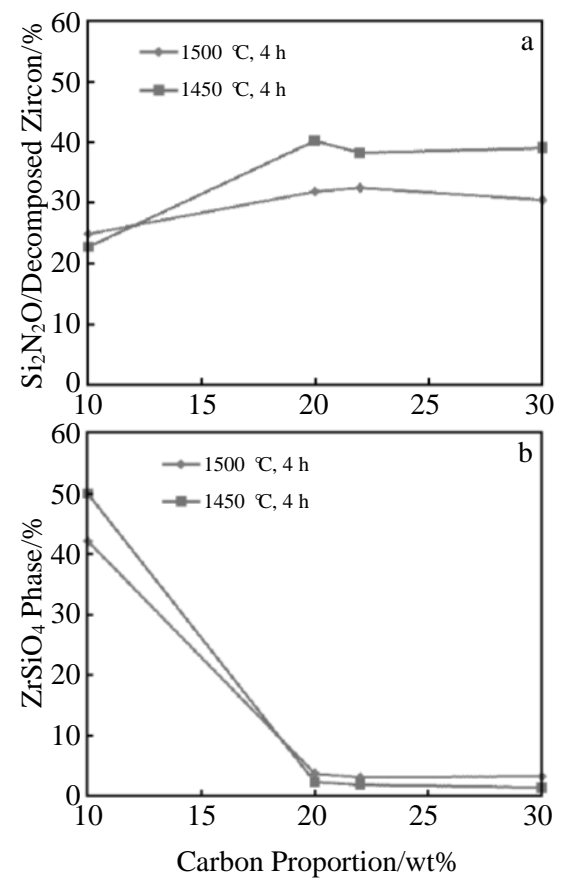

Fig.4 Effect of carbon proportion on $\mathrm{Si}_{2} \mathrm{~N}_{2} \mathrm{O}$ /decomposed zircon ratio (a) and content of $\mathrm{ZrSiO}_{4}$ (b)

It can be seen from Fig.3a, when carbon proportion is $10 \%$, the actual mass loss is larger than the theoretical value calculated from Fig.3. It may be explained by the following equation:

$$
\mathrm{ZrSiO}_{4}+\mathrm{C} \rightarrow \mathrm{ZrO}_{2}+\mathrm{SiO}(\mathrm{g})+\mathrm{CO}(\mathrm{g})
$$

The high mass loss results from $\mathrm{SiO}$ volatilization. However, in other specimens with higher carbon proportion, the actual mass loss is smaller than the theoretical mass loss. Moreover, the higher the carbon proportion is, the bigger the difference between the actual mass loss ratio and the theoretical one is. This fact can be explained by the following equations:

$$
\begin{aligned}
& 3 \mathrm{SiO}(\mathrm{g})+3 \mathrm{C}+2 \mathrm{~N}_{2} \rightarrow \mathrm{Si}_{3} \mathrm{~N}_{4}+3 \mathrm{CO}(\mathrm{g}) \\
& 2 \mathrm{SiO}(\mathrm{g})+\mathrm{C}+\mathrm{N}_{2} \rightarrow \mathrm{Si}_{2} \mathrm{~N}_{2} \mathrm{O}+\mathrm{CO}(\mathrm{g})
\end{aligned}
$$

Fig.4a shows that the ratios of $\mathrm{Si}_{2} \mathrm{~N}_{2} \mathrm{O}$ and the decomposed zircon in the samples increase obviously with carbon proportion increasing from $10 \%$ to $20 \%$, which means with the increase of carbon proportion, the volatilization of $\mathrm{SiO}$ decreases. Therefore, the carbon proportion can be increased for improving the content of silicon-rich phases such as $\mathrm{Si}_{2} \mathrm{~N}_{2} \mathrm{O}, \mathrm{Si}_{3} \mathrm{~N}_{4}$ or $\mathrm{SiC}$. However, this results in residual free carbon after reaction, which can hardly be eliminated without degrading the nitride.

\subsection{Effect of carbon proportion on phase composition of the specimens}

Fig. 5 shows the XRD patterns of the samples with different carbon proportions after reacted at $1500{ }^{\circ} \mathrm{C}$ for $4 \mathrm{~h}$.

The expected products of sample A10 are $\mathrm{ZrO}_{2}$ and $\mathrm{Si}_{2} \mathrm{~N}_{2} \mathrm{O}$ according to the thermodynamics analysis, but the actual products of sample A10 include $m-\mathrm{ZrO}_{2}, \mathrm{Si}_{2} \mathrm{~N}_{2} \mathrm{O}$, undecomposed $\mathrm{ZrSiO}_{4}$ and intermediate phase $\mathrm{Zr}_{7} \mathrm{~N}_{8} \mathrm{O}_{4}$, as shown in Fig.5.

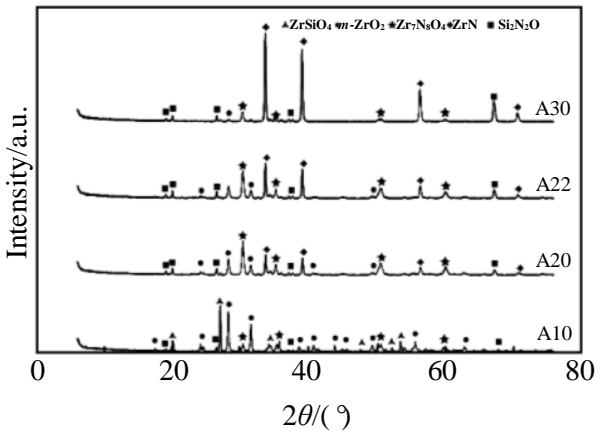

Fig.5 XRD patterns of the samples with different carbon proportions after heat treated at $1500{ }^{\circ} \mathrm{C}$ for $4 \mathrm{~h}$

During the phase analysis of the samples after heat treated, $\mathrm{Zr}_{7} \mathrm{O}_{8} \mathrm{~N}_{4}$ is identified as $c-\mathrm{ZrO}_{2}$ at first because the $\mathrm{Zr}_{7} \mathrm{~N}_{8} \mathrm{O}_{4}$ phase shows the diffraction peaks which are very similar to that of $c-\mathrm{ZrO}_{2}$, except that some additional very small superlattice reflections cannot be observed in $c-\mathrm{ZrO}_{2}{ }^{[8,9]}$. It is well known that $c-\mathrm{ZrO}_{2}$ is hard to exist stably at room temperature without the existence of stabilizer. In this work the stabilizer isn't introduced. How is the existence of $c-\mathrm{ZrO}_{2}$ explained? Claussen et al. ${ }^{[10]}$ researched the phase composition after the nitridation of $\mathrm{ZrO}_{2}$ and called this phase as 'nitrogen stabilized cubic zirconia'. While Lerch et al. ${ }^{[11]}$ regarded that this phase is zirconium nitrogen oxide and called it as $\beta$-type phase, which it is the general term of $\beta\left(\mathrm{Zr}_{7} \mathrm{O}_{8} \mathrm{~N}_{4}\right), \beta^{\prime}\left(\mathrm{Zr}_{7} \mathrm{O}_{11} \mathrm{~N}_{2}\right)$ and $\beta$ ' $\left(\mathrm{Zr}_{7} \mathrm{O}_{9.5} \mathrm{~N}_{3}\right)$ in $\mathrm{ZrO}_{2}-\mathrm{Zr}_{3} \mathrm{~N}_{4}$ binary system with general chemical formula of $\mathrm{ZrO}_{2-2 x} \mathrm{~N}_{4 x / 3}$, as shown in Fig.6.

In order to prove that the $c-\mathrm{ZrO}_{2}$ should be zirconium oxynitride, the specimen A30 was fired at $1500{ }^{\circ} \mathrm{C}$ for $4 \mathrm{~h}$ in Ar atmosphere, and its XRD pattern is shown in Fig.7.

Fig.7 shows that the products of A30 after reacted in Ar atmosphere include $m-\mathrm{ZrO}_{2}, \mathrm{ZrC}$ and $\mathrm{SiC}$, while $c-\mathrm{ZrO}_{2}$ phase is not formed. This fact confirms that $c-\mathrm{ZrO}_{2}$ in the CRN products of zircon is zirconium oxynitrides. XRD analysis shows that the yielded zirconium oxynitride mainly consists of $\beta$ phase with chemical formula of $\mathrm{Zr}_{7} \mathrm{O}_{8} \mathrm{~N}_{4}$ in this work.

According to thermodynamic analysis, the expected prod-

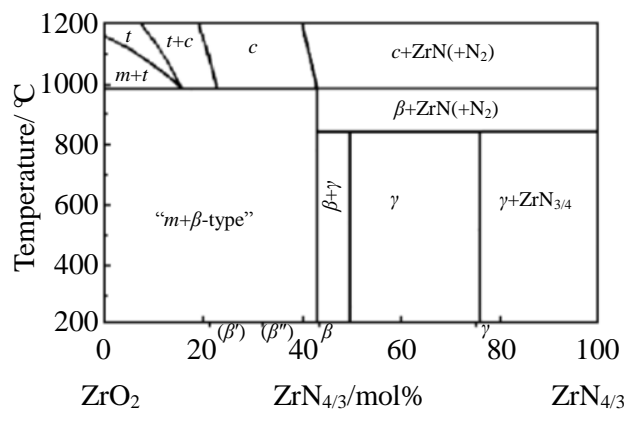

Fig.6 Observed phases in $\mathrm{ZrO}_{2}-\mathrm{Zr}_{3} \mathrm{~N}_{4}$ system ( $c$ : cubic fluorite structure; $t$ : tetragonal distorted fluorite structure; $m$ : monoclinic baddeleyite structure; $\beta / \beta^{\prime} / \beta^{\prime \prime}: \beta$-type phases $)^{[11]}$ 


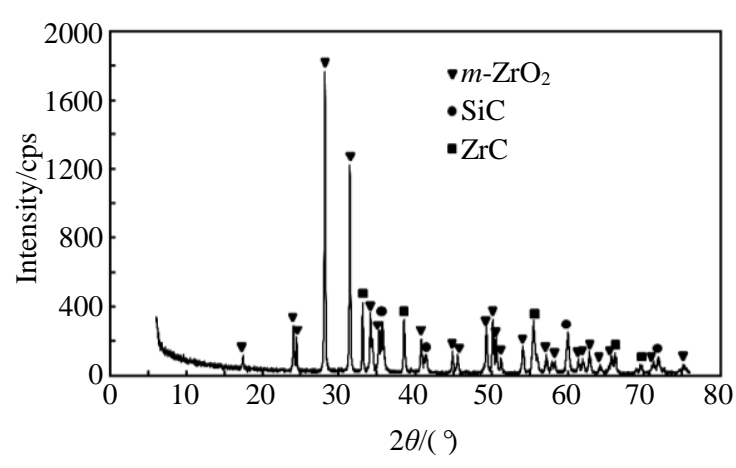

Fig.7 XRD pattern of the sample A30 after reaction in $\mathrm{Ar}$ atmosphere at $1500{ }^{\circ} \mathrm{C}$ for $4 \mathrm{~h}$

ucts of sample A20 are $\mathrm{ZrN}$ and $\mathrm{Si}_{2} \mathrm{~N}_{2} \mathrm{O}$. Besides these expected phases, the actual product phases also include much $m-\mathrm{ZrO}_{2}$ and $\mathrm{Zr}_{7} \mathrm{O}_{8} \mathrm{~N}_{4}$, and a trace of undecomposed $\mathrm{ZrSiO}_{4}$. XRD semi-quantitative analysis shows that the content of $\mathrm{Si}_{2} \mathrm{~N}_{2} \mathrm{O}$ is consistent with the expect value, but the content of $\mathrm{ZrN}$ is less than the expect value, only about $10 \mathrm{wt} \%$. The main reason can be attributed to the reaction unbalance, which depends on the parameters of dynamic such as temperature and time.

When carbon proportion is larger than $22 \mathrm{wt} \%$, the expected phases of samples are $\mathrm{ZrN}$ and $\mathrm{Si}_{3} \mathrm{~N}_{4}$. In fact the products are $\mathrm{ZrN}, \mathrm{Si}_{2} \mathrm{~N}_{2} \mathrm{O}$, little $\mathrm{Zr}_{7} \mathrm{O}_{8} \mathrm{~N}_{4}$ and $m-\mathrm{ZrO}_{2}$, and a trace of $\mathrm{ZrSiO}_{4}$. The actual product being $\mathrm{Si}_{2} \mathrm{~N}_{2} \mathrm{O}$ instead of $\mathrm{Si}_{3} \mathrm{~N}_{4}$ mainly is because of the higher practical pressure of $\mathrm{CO}$ or low reaction temperature.

In sample A10 the amount of undecomposed zircon after reacted at $1500{ }^{\circ} \mathrm{C}$ is still very high as shown in Fig.4b and Fig.5. While in other samples, the content of $\mathrm{ZrSiO}_{4}$ is lower than $3 \mathrm{wt} \%$, meaning that the zircon has disappeared after reacted at $1450{ }^{\circ} \mathrm{C}$. This result shows that the increase of carbon proportion can accelerate the decomposition of $\mathrm{ZrSiO}_{4}$. Therefore, the starting temperature of reaction can decrease by increasing of carbon proportion.

\section{Conclusions}

1) The stability domains of product phases for CRN of zircon have relation to processing parameters such as reaction temperature, partial pressures of $\mathrm{CO}$ and $\mathrm{N}_{2}$. Different oxide-nitride composite materials such as $\mathrm{ZrO}_{2}-\mathrm{Si}_{2} \mathrm{~N}_{2} \mathrm{O}$, $\mathrm{ZrN}-\mathrm{Si}_{2} \mathrm{~N}_{2} \mathrm{O}$, and $\mathrm{ZrN}-\mathrm{Si}_{3} \mathrm{~N}_{4}$ can be prepared by controlling carbon proportion and reaction conditions. $\mathrm{Zr}_{7} \mathrm{O}_{8} \mathrm{~N}_{4}$ is an intermediate phase in these reactions.

2) Different carbon proportions result in different reaction products. With the increase of carbon proportion, the starting temperature of $\mathrm{CRN}$ of zircon decreases.

\section{References}

1 Ma Beiyue, Yu Jingkun, Liu Tao et al. Refractories[J], 2009, 43: 343 (in Chinese)

2 Ma Beiyue, Yu Jingkun. Rare Metals[J], 2009, 28: 367

3 Ma Beiyue, Yu Jingkun. Transaction of Nonferrous Metal of China[J], 2009, 19: 1222

4 Yu Renhong, Fu Yadong, Zhang Mengmeng et al. China's Refractories[J], 2011, 20: 6

5 Zhang Mengmeng, Yu Renhong, Zhou Ningsheng. Refractories[J], 2011, 45(5): 350 (in Chinese)

6 Mazzaoni A D, Aglietti E F. Materials Chemistry and Physics[J], 2000, 65: 166

7 Chen Zhaoyou. Chemical Thermodynamics of Refractories[M]. Beijing: Metallurgical Industry Press, 2005: 648 (in Chinese)

8 Lerch M, Krumeich F, Hock R. Solid State Ionics[J], 1997, 95: 87

9 Lerch M. Journal of American Ceramic Society[J], 1996, 79: 2641

10 Claussen N, Wagner R, Gaucker, L J et al. Journal of American Ceramic Society[J], 1978, 61: 369

11 Lerch M. Journal of Materials Science Letters[J], 1998, 17: 441

\title{
Zr-Si-C-N-O 系复相材料的制备及热力学分析
}

\author{
于仁红，周宁生，张菲菲 \\ (河南科技大学, 河南 洛阳 471003)
}

\begin{abstract}
摘 要: 为了得到钻英石碳热还原氮化反应时产物相的稳定存在区域, 用 $\Delta_{\mathrm{f}} G_{i}^{\Theta}=A+B T$ 法对Zr-Si-C-N-O系进行了热力学计算和分析, 绘制了Zr-Si-C-N-O系优势区相图。结果表明: 通过控制配碳量、反应温度、炉内的CO分压和 $\mathrm{N}_{2}$ 分压, 可以获得组成分别为 $\mathrm{ZrO}_{2}-\mathrm{Si}_{2} \mathrm{~N}_{2} \mathrm{O}$ 、 $\mathrm{ZrN}-\mathrm{Si}_{2} \mathrm{~N}_{2} \mathrm{O}$ 或 $\mathrm{ZrN}-\mathrm{Si}_{3} \mathrm{~N}_{4}$ 等的复相材料。根据热力学分析结果, 以钻英石、活性炭为原料, $\mathrm{N}_{2}(99.999 \%)$ 为氮源, 研究了配碳量 (10\%, $20 \%, 22 \% ， 30 \%$, 质量分数）对铅英石碳热还原氮化反应失重率及产物相组成的影响。结果表明: 配碳量不仅显著影响铅英石碳热还 原氮化反应产物的物相组成，而且配碳量的增加还会降低锆英石碳热还原氮化反应的开始温度。
\end{abstract}

关键词：锆英石；碳热还原氮化；热力学分析；优势区相图；配碳量

作者简介：于仁红，女，1977 年生，博士，副教授，河南科技大学高温材料研究院，河南 洛阳 471003，电话：0379-64231460, E-mail: yurenhong_wby@sina.com 